\title{
Development of National Insights through Education and Scouting Training in the Environment of Modern Islamic Boarding School Darussalam Gontor Ponorogo Indonesia
}

\author{
Dr. H. M. Yunus Abu Bakar, M.Ag ${ }^{1 *}$, Dr. Hj. Mardiyah, M.Ag ${ }^{2}$
}

${ }^{1}$ Post Graduate Lecturer of the State Islamic University of Sunan Ampel Surabaya, Indonesia

${ }^{2}$ Lecturer of Faculty af Tarbiyah and Teachers Training of the State Islamic University of Sunan Ampel Surabaya, Indonesia

\author{
DOI: $10.36348 /$ sjhss.2020.v05i08.004 \\ | Received: 24.07.2020 | Accepted: 03.08.2020 | Published: 20.08.2020
}

*Corresponding author: Dr. H. M. Yunus Abu Bakar

Abstract

The spirit of Islamic institution in instilling a nationalist insight at the time of independence is always carried out to instill the country's defense. Developing a national insight toward Santri can be done in a variety of ways and activities. The purpose of this research is to find out the implementation of training and scouting education, the development of nationalism insight, supporting factors, obstacles or obstacles that arise, and the solutions made in Gontor Modern Islamic boarding school environment. The research method used in this research was qualitative method to answer the research problem accordance with the phenomena that occurred in the Developing the Nationality Insights through Education and Scouting Training at Gontor Modern Islamic boarding school Environment. The data collection techniques were done by doing observations, conducting interviews, and analyzing some relevant documentations. The techniques to check the validity of data was based on holding certain criteria. The data validity criteria were based on four things, namely the degree of trust or credibility, transferability, dependability, and confirmability. The criteria for data collection were examined using detailed description techniques, the criteria for dependency and certainty were carried out by auditing. The technique of checking the validity data was carried out by the evidences.

Keywords: Development, national insights, education and scouting training.

Copyright @ 2020: This is an open-access article distributed under the terms of the Creative Commons Attribution license which permits unrestricted use, distribution, and reproduction in any medium for non-commercial use (NonCommercial, or CC-BY-NC) provided the original author and source are credited.

\section{INTRODUCTION}

Islamic Boarding School in the history of Indonesian nationality defines as a unique and distinctive appearance that related to the struggle of the Indonesian nation. The position of this Islamic institution in deciding the fate of the nation can be seen from the fight against colonialists in the Dutch colonial period. During the Japanese occupation, Islamic Boarding School returned to be witnesses toward the heroism of the Islamic teacher as known as Kiai and Islamic students as known as Santri in driving a rebellion to drive out Japan. The spirit of this Islamic institution in instilling a nationalist insight at the time of independence is always carried out to instill the country's defense.

The development of nationalism aims to develop the spirit of Santri's nationalism. Nationalism means self-awareness that is manifested by a deep love for the country or the motherland [1]. Nationalism aims to guarantee the willingness and strength to maintain national society against the enemy and to create a spirit of self-sacrifice for the State interest. Nationalism holds a manifestation of people's love for the country based on an attitude of upholding human values and tolerance. The spirit of nationalism must be owned by every citizen generally, and the younger generation particularly.

The young generation signifies as the next generation of the nation that expected to be able to make a significant contribution and to the progress of the nation. They must have a strong spirit of nationalism and critical thinking. The spirit of their nationalism cannot be owned instantly. Hence, the

\footnotetext{
${ }^{1}$ Hardjosatoto, dkk., Sejarah Pergerakan Nasional Indonesia dari Budi Utomo sampai Proklamasi (Yogyakarta: Liberty,1985), 42
} 
instilling and determination of the attitude of nationalism has to be conducted early on.

Developing a national insight toward Santri can be done in a variety of ways and activities. One of those is through scouting activities. It holds a youth organization that has a clear vision and mission to develop education outside of school. Scouting activities aim to prepare the young generation as the nation's bud. In time, they will accept the relay stick of their predecessor's struggle to continue the struggle to complete the ideals of the nation and at last to realize a just and prosperous society [2].

As a youth organization that develops scouting education, its movement has very close links with formal education. Scouting activities are extracurricular activities that must be carried out to every elementary and secondary school until in tertiary level, both public and private institutions. This proves that scouting activities are very important for the needs of human life. Furthermore, the activities signify the manifestation of the efforts to defend the State and to love the State [3].

Scout Education has a role as a complement to formal education. The purposes of the scouting movement in Indonesia made based on the decision of the national Scout Movement Number 203 of 2009. The decision is concerned with the statutes and bylaws that is stated that "the realization of young Indonesian people who prepared to become, (a) humans with character, personality, noble character, high intelligence, skills and healthy physical; (b) citizens with the spirit of Pancasila as the basic country law, loyal and obedient to the Unitary State of the Republic of Indonesia, a good and useful member of society who can build themselves independently including jointly be responsible for the development of the nation and the state, they have concern for fellow life and natural environment at the local, national and international level" [4].

Regarding with the above phenomena, the establishment of a strong personality and sense of responsibility as citizens as well as an understanding of national insights need to be developed toward all young generations from an early age. This can be sought through scouting education. This education has a strategic function about the basis for the fostering of national identity which is included as one of the main assets in building the nation presently and in the future. Moreover, it has the potential sense to develop nationalist insights such as patriotism and nationalism

\footnotetext{
${ }^{2}$ A. Chaedar Alwasilah, Filsafat Pramuka (Bandung; Rosdakarya, 2008), 59

${ }^{3}$ Ibid., 65

4 Kwartir Nasional Gerakan Pramuka. Gerakan Pramuka Anggaran Dasar dan Anggaran Rumah Tangga, 2009
}

which all provide a unique insight in living the national values.

The research entitled: "Development of national insights through education and scouting training in the environment of modern islamic boarding school Darussalam Gontor" is considered very necessary to be studied in depth. Because of Pondok Modern Darussalam (continuously written by PMD) Gontor as a boarding school institution that develops the education and training of the boarding system to the maximum and as an obligation activity for all students. The purpose of this research is to find out the implementation of training and scouting education, the development of nationalism insight, supporting factors, obstacles or obstacles that arise, and the solutions made in Gontor PMD environment.

Nationality insight is a person's perspective on the nation, its environment, and the way on how to express their nationality in a developing environment. National insight is not only a demand to realize one's identity, but also to foster behavior as a nation that believes in its intrinsic values (usually named as Astawa) [5].

The nationalism insight of Indonesia is developed and crystallized. Moreover, it cannot be separated from the history of the Indonesian people used to. The concept of Indonesian nationalism was realized when the Youth Pledge was held in the Youth Congress on October 28, 1928. The Pledge was an effort to unite youths throughout Indonesia who wished to unite and to fight the invaders. Youths from all over Indonesia from Sabang to Merauke joined to pledge by stating, "one nation, one language and one homeland of Indonesia". However, the whole of that will be only a memory document if people do not have a national insight. National insight is needed as a filter for the values of globalization that is not under the life philosophy of the nation which it can crush the unity and integrity of the Indonesian nation.

To be able to understand the thought of nationalism, we need to comprehend the meaning of "nation" at the beginning. Term of "nation" has a definition that tends to the same group of people regarding their origin, ancestry, language, and history. Meanwhile, according to Otto Bauer (cited in Suhady and Sinaga) [6] "nation" holds a unity of character that arises because of the union of fate. (Eine Nation ist eine aus Schicksal gameinschaft erwachsene Character

\footnotetext{
5 Dewa Nyoman Wija Astawa, Pola Pikir Meningkatkan Wawasan Kebangsaan Mencegah Disintegrasi Bangsa (Surabaya: Paramita, 2011), 7

${ }^{6}$ Idup Suhady dan A.M. Sinaga, Wawasan Kebangsaan dalam Kerangka Negara Kesatuan Republik Indonesia (Jakarta: Lembaga Administrasi Negara Republik Indonesia, 2006), 99
} 
gerneinschaft). Otto Bauer concerns more on understanding the nation as a character, attitude, and behaviour that becomes an identity towards other nations. This character is created because of historical, cultural experiences, which grow together with the growth and development of the nation. Another case with Ernest Renan (cited in Suhady and Sinaga) [7] reveals that the term of "nation" denotes as a group of people who have the will to unite so that they feel they are one. Thus, the main factor that gives rise to a nation is the will of each citizen to establish a nation.

Based on those above definitions, it resembles that "the nation" implies: (1) having shared ideals that unite them together as one, (2) having a history of living together, to create a sense of unity in harmony, (3) having the same customs, culture, habits as a result of the experience like living together, (4) has the same character/temperament.

After understanding the meaning of "nation", then we need to know about the meaning of "nationality". According to the Big Indonesian Dictionary [8], this term indicates (1) the characteristics that mark the national class; (2) concerning with the nation; (3) self-awareness as citizens of a country. While the term of "insight" according to the Big Indonesian Dictionary [ 9 ], it indicates the understanding of (1) inspecting results; review; view; and (2) conception of perspective. Thus, national insight can be understood as a representation of perspective based on self-awareness as citizens of a country of themselves and their environment in the life of the nation and state. Moreover, the concept of nationalism is portrayed as the nation's perspective on self and its environment based on national philosophy, ideals, and goals or ideology as well as possible adjustments in a developing world (Wasbang Socialization Team) [10]. Meanwhile, according to Hargo [11] the concept of nationalism holds an effort in the context of enhancing the sense of citizens' nationalism as a united and sovereign state within the territory of the Unitary Republic of Indonesia. To sum up, the concept of nationalism is defined as a way of

\footnotetext{
${ }^{7}$ Ibid., 100

8 Pusat Bahasa Departemen Pendidikan Nasional. Kamus Besar Bahasa Indonesia, 102

${ }^{9}$ Ibid., 127

${ }^{10}$ Tim Sosialisasi Wawasan Kebangsaan,. Himpunan Modul Sosialisasi Wawasan Kebangsaan. Edisi Kedua. (Jakarta: Sekretariat Negara Republik Indonesia, 2005), 21-22

11 Dodi Usodo Hargo, Makalah Kuliah Umum Pemahaman Wawasan Nusantara Sebagai Wawasan Kebangsaan Indonesia Dalam Rangka Membangun Ketahanan Nasional (Kupang: Universitas Nusa Cendan, 2010), 5
}

citizens' view concerning to the existence and matters related to the nation and state (Darmono) [12].

Regarding the various notions of national insight above, it can be inferred that the national insight is essentially the same way of looking at a nation is looking at itself and its environment concerning ideals that will provide direction and passion for life and the goals to be achieved. In the Indonesian context, the perspective of the Indonesian people is based on the ideology of Pancasila and the constitutional foundation of the 1945 Constitution.

Scout or as known as Praja Moeda Karana is originated from Sanskrit, which it has a meaning. First, the word Praja means "citizens", second, the word Moeda means those who have young souls, and the word Karana symbolizes the ability and tenacity in creating. In line with the statement, Scout Movement National of Kwartir [13] reveals that Scouting defines as an educational process that was done outside of the school and family environment. Moreover, the activities are covered in the form of interesting, fun, healthy, organized, directed, practical activities that those still carried out the basic scouting principles and scouting methods whose ultimate goal tends to the way to build noble character [14].

Joko Mursitho reveals that scouting implies a process of education outside the school environment and outside the family environment in the form of activities that are interesting, fun, healthy, organized, directed, practically carried out in the open with the basic principles of scouting and scouting methods that ultimately form character [15]. Based on some of the explanations above, it can be concluded that scouts are members of the scouting movement and it carries out scouting activities. While Scouting is an education that is carried out outside the school and family environment in the form of interesting and enjoyable activities for young people under the responsibility of grown-up members that was conducted in the nature field by applying the basic principles of scouting and scouting methods whose ultimate goal is character building.

The purpose of the scout movement is described in Act Number 12 of 2010 concerning the Scout Movement article 4. The act states that the scout

\footnotetext{
${ }^{12}$ Bambang Darmono, Makalah Pembekalan Kepada Perwira Siswa Sesko Ketiga Angkatan (Bandung: Graha Widya Dirgantara, 2010), 18

${ }^{13}$ Sarkonah, Panduan Pramuk: Penggalang ( Bandung: CV. Nuansa Aulia, 2011), 3

14 Kwartir Nasional Gerakan Pramuka, Gerakan Pramuka Anggaran Dasar dan Anggaran Rumah Tangga (Jakarta: Kwarnas, 2009), 23.

${ }^{15}$ Joko Mursitho, Kursus Mahir Dasar untuk Pembina Pramuka (Kulonprogo: Kwarcab Kulonprogo, 2010), 22.
} 
movement aims to build a faithful personality, religious, noble, patriotic, law-abiding, discipline, upholds the nation's noble values, and someone who have life skills as a candidate of the nation in protecting and developing the Unitary State of the Republic of Indonesia, practicing Pancasila, and preserving the environment [16]. The scouting movement as a scouting education organizer in Indonesia with national education aims to foster young people in achieving their full spiritual, social, intellectual, and physical potentials.

In the Articles of Association and Bylaws of the Scout Movement chapter II article 3 reads:

a. Scout Movement aims to create a scout who has a personality such as faithful, pious, noble, patriotic, law-abiding, disciplined, upholding the noble values of the nation, life skills, healthy physical and spiritual.

b. The Scout Movement aims to create the members in order to be a good citizen with the thought of Pancasila as nation ideology. Then, create the members with loyal and obedient ones to the Unitary State of the Republic of Indonesia including being a good and valuable member of society who can build himself independently and jointly take responsibility for the development of the nation and state. They have sense of care for fellow life and the natural environment [17].

The scout movement has the main task of organizing scouting education for young people such as to grow the nation's buds, to become a better generation, to be responsible, to be able to foster and fill independence including building a better world. Through the scout movement, students will gain additional experience, skills, and knowledge. With a variety of potentials developed in scouting, students are expected to be able to build themselves into cadres who are moral, patriotic, nationalist, defending the country, disciplined, and participating in the development of society and the state.

In its implementation, scouting education is based on a system, by applying the basic principles of scouting and scouting methods. The scouting movement instructs Indonesian young people with the basic principles of scouting and scouting methods whose implementation is harmonized with the conditions, interests, and development of the Indonesian nation and society so that they become better human beings, useful for the development of the nation and state. In the

16 Undang-Undang Republik Indonesia Nomor 12 Tahun 2010 Tentang Gerakan Pramuka, 4

17 Kwartir Nasional Gerakan Pramuka, Gerakan Pramuka Anggaran Dasar dan Anggaran Rumah Tangga (Jakarta: Kwartir Nasional Gerakan Pramuka, 2014), 7.
Articles of Association and Bylaws present a more indepth explanation of the Among systems, the basic principles of scouting and scouting methods as follows:

\section{Among Systems}

In performing the scouting education, the mantaining system is used. This system is defined as the process of scouting education that shapes students to have an independent, discipline, and independent spirit in mutual relations between people [18]. In the Law of the Republic of Indonesia number 12 of 2010 concerning Scout Movement article 10 reveals that the Among system is implemented by applying the principles of leadership:

1. Ing ngarso sung tulodho means to be an example in the future.

2. Ing madyo builds karo in the middle of building the desires.

3. Tutwuri handayani means behind encouraging, and good influence towards independence [19].

According to the three leadership principles in the Among System mentioned above, it provides an overview of the relationship concerning with the adult scout members or educators with their students. The first principle emphasizes that Scouting Education is carried out by way of instance. In scouting activities, scouting values reflected in the words and actions of educators will be observed, understood, and can be imitated by students. The second principle that is in the middle or among student which educators must be able to create initiatives and ideas. Meanwhile, the third principle explains from behind an educator must provide encouragement, direction, and build motivation towards being positive under the goals of scouting education.

Islamic Boarding School derives from the word Santri which it can be described as Santri's place [20]. The word "Santri" itself derived from the word Cantrik (Sanskrit) which means people who always follow the teacher. Then, it is developed by Taman Siswa Institution in the boarding system. Poerwadarminta defines Islamic Boarding School as a dormitory and a place for students to study Qur'an [21].

In line with the above definitions, Imam Zarkasyi adds more that Islamic Boarding School defines as Islamic educational institutions with a boarding system, where Kiai as the central figure,

\footnotetext{
${ }^{18}$ Ibid., 9

19 Undang-Undang Republik Indonesia Nomor 12 Tahun 2010 Tentang Gerakan Pramuka, 5

${ }^{20}$ Zamakhsyari Dhoefier, Tradisi Pesantren: Studi Tentang Pandangan Hidup Kiai (Jakarta: LP3ES, 1982), 18

21 WJS. Poerwadarminta, Kamus Umum Bahasa Indonesia (Jakarta: Balai Pustaka, 1982), 764
} 
mosque as the center of activities place, and the teaching of Islamic lesson under the guidance of Kiai followed by Santrias its main activity. According to Abdurrahman Wahid, the Islamic Boarding School can be seen as a laboratory of life, where students learn life and society in various aspects [22].

By understanding some limitations and definitions above, it can be said that the Islamic boarding school contains several elements, namely Kiai, boarding school, mosque, Santri, and the ativities in learning some classical Islamic books [23]. Experts generally have the same view in determining the elements of the Islamic boarding school however they are different in determining the subject matter and teaching methodology. Zamakhsyari, for example, the way to define subject matter of Islamic boarding school, they only limit to classical books with traditional teaching methodologies, namely sorogan and wetonan, while Imam Zarkasyi does not limit subject matter to classical books and prefers to use the methodology of teaching classical systems.

This can be understood due to the model of the guidance system that applies in one boarding school is not necessarily the same as the system in others. The difference in building characteristics cannot be separated from the central role of the Kiai in each Islamic boarding school and the social environment in a particular space and time. However, presumably, there is one thing that carries the movement, namely departing from religious attitudes and beliefs, and oriented to community development [24].

The Islamic boarding school in terms of its form and system were originated from India. The education system in this boarding school has similarities with the Kalla teacher system in mainland India. Before the process of spreading Islam in Indonesia, the Islamic system had been used generally for teaching and become the education system of Hinduism in Java. Then this education was Islamized without leaving existing traditions. The basic difference is that during the Hindu period, education only belonged to a certain caste, while during the Islamic era, the education belonged to everyone regardless of ancestry and position because in Islam's view all humans are egalitarian people.

The presence of an Islamic boarding school in Indonesia for the first time, where, and who its founder was, it cannot be obtained with certain information. There is an opinion that says that this school type was

\footnotetext{
${ }^{22}$ Abdurrahman Wahid, Menggerakkan Tradisi; EsaiEsai Pesantren, (Yogyakarta: LKIS, 2001), 17

${ }^{23}$ Zamakhsyari Dhoefier, Tradisi Pesantren: Studi Tentang Pandangan Hidup Kiai, 44

${ }^{24}$ Nurcholish Madjid, Bilik-Bilik Pesantren (Jakarta: Paramadina, no year), 135
}

first established by Sheikh Maulana Malik Ibrahim. He was a scholar from Gujarat, India. Despite so, the figure who was considered successful in establishing and developing this school in the real sense was Raden Rahmat or Sunan Ampel. He found a boarding school in Kembang Kuning, which at the time of its establishment only had three students; they were Wiryo Suroyo, Abu Hurairah, and Kyai Bangkuning. Then he moved to Denta, Surabaya, and established an Islamic boarding school there, and finally, he was known as Sunan Ampel.

The Islamic boarding school is defined as an educational institution and a social institution for the community that has the flexibility and resistance to face any dynamic times. In colonial times, this school did uzlah (shuted off) to the system under colonialism, including in the field of education. However, at this time to remain relevant to people's lives, this school exposes itself by adopting a modern classical education system.

As what has been known as now, the Islamic boarding school still survives as an educational institution that is in demand by the community during a wave of rapid changes in social life. All that happened because it can carry out the process of caring for good traditions and at the same time adopting new scientific developments better.

\section{RESEARCH METHOD}

The research method used in this research was qualitative method to answer the research problem accordance with the phenomena that occurred in the Developing the Nationality Insights through Education and Scouting Training at Gontor Modern Islamic boarding school Environment. Qualitative research defines as an approach in conducting research that is oriented to natural phenomena or symptoms [25].

The setting of this study was done firstly at PMD Gontor Ponorogo and the second one was in PMD Gontor Putri Mantingan Ngawi as a sample of the whole Pondok Modern institutions consisting of 20 boarding schools (13 Pondok Gontor Male and 7 Pondok Gontor Female). The subject of this research was investigated on the developing the nationality insights through education and scouting training at gontor modern Islamic boarding school environment as a representative toward the development of the nationality insight for the Santri (Islamic male students) and Santriwati (Islamic female students) along the boarding school environment.

The data source in this research was derived from the results of interviews and observations about certain events that occurred in scouting education and

\footnotetext{
${ }^{25}$ Muhammad Ali, Memahami Riset Prilaku dan Sosial (Bandung: Pustaka Cendekia Utama, 2011), 239.
} 
training in the context of developing a national outlook among the students in this boarding school. The data collection techniques were done by doing observations, conducting interviews, and analyzing some relevant documentations.

The techniques to check the validity of data was based on holding certain criteria. The data validity criteria were based on four things, namely the degree of trust or credibility, transferability, dependability, and confirmability. The criteria for data collection were examined using detailed description techniques, the criteria for dependency and certainty were carried out by auditing. The technique of checking the validity data was carried out by the evidences [26].

Data analysis signifies the process of organizing and sorting data into basic patterns, categories, including description units, It must be done so that the issues can be found and hypotheses can be formulated as suggested by the data. The steps of data analysis included organizing data, make it in order, grouping, coding, and categorizing the data. The purpose of organizing and managing the data is to obtain work themes and hypotheses which will eventually become substantive theories [27].

The data analysis process was started with a review of all available data from various sources, namely from interviews, observations that have been written in the field notes, personal documents, official documents, pictures, and so on. Among a lot of data with the process after being read, studied, and analyzed. The next step was data reduction. Reduction of the data was done to carry out the abstractions.

Abstraction defines as an attempt to make a summary of the core, process, and statements that need to be maintained so that it remains in it. The next step was to arrange the whole data in units. The units were categorized in the next step. The categories were carried out while did coding. The final stage of the data analysis was done by checking the data validity. After completing this stage, the data interpretation process in processing provisional results started to become a substantive theory using several specific methods [28].

\section{FINDINGS}

The implementation of scout education and training

The front line, or in Indonesian was known as Gugus depan (Gudep). That term is defined as an organic unit in the Scout Movement which is involved a forum for gathering members of the Scout Movement as

\footnotetext{
${ }^{26}$ Lexy J. Moleong, Metodologi Penelitian Kualitatif, 173.

${ }^{27}$ Lexy J. Moleong, Metodologi Penelitian Kualitatif, 103.

${ }^{28}$ Lexy J. Moleong, Metodologi Penelitian Kualitatif, 190.
}

students, scout coaches and serves as a base for student membership [29]. This line meant was the forerunner to the formation of Scouting "Islamic Stars" by KH. Ahmad Sahal, with training programs including scouting skills, art training, exploration, agriculture, animal husbandry, leadership, and so forth. Even vacation times were used for camping activities around the campus under the direct supervision of KH. Ahmad Sahal. Currently, the scouting activities at PMD Gontor is handled by the Front line Coordinator of Islamic boarding school Modern Gontor under the guidance and supervision of the Daily Coordinating Advisory Board [30].

Some of the scouting movement activities that could be categorized as scouting education were as follows:

Period)

a) BAC (Basic Advanced Course)

b) DCP (Development and Consolidation

c) Marching Band Course

d) AAC (Advanced Advanced Course)

e) BTC (Basic Trainers' Course)

f) ATC (Advanced Training Course)

Some of the scouting movement activities that could be categorized as scouting training included:

a. Scouting Training

a) Training activities on campus

b) $30^{\text {th }}$ Enforcement and Enforcement Camp Contest

c) Thursday-Friday Campsite

d) Search and Rescue (SAR) training

e) Sending contingents to National Jamboree and World Jamboree

f) Participating in the $4^{\text {th }}$ ASEAN Jamboree

g) Garuda Scout $\left[{ }^{31}\right]$.

b. Scouting Organization Training

a) Coordinator Work Meeting

b) Front Line Conference

c) Leadership Development Training

\footnotetext{
${ }^{29}$ SK Kwarnas Gerakan Pramuka No: 137 of 1987 , chapter I

${ }^{30}$ In each Front line there is Front Line Guidance Council and in the whole Front line is coordinated by the Scout Movement Coordinator, and in the Coordinator, there is Daily Supervising Coordinator Council. The data was obtained by Interviewing Ust. Gunawan Andi Pranata, S.Pd, Chair of Front Line Guidance Council, September 2, 2018, in the office of PM Gontor's Scout Movement Coordinator

${ }^{31}$ Garuda Scout is the highest level in each group of Scouts from Standby, Riser, Enforcement, and Pandega (the older group after Enforcement level). Garuda Scouting is regulated in the National Scout Decree of the Scout Movement Number 101 of 1984 concerning Garuda Scout Operation Guidelines.
} 
d) Accountability and Inauguration Report Mainstay of the Coordinator and Front line coordinator

Development of Nationality Insights through Training and Education of Scouting in the Gontor PMD Environment

The implementation of national value education through scouting activities at PMD Gontor Ponorogo was carried out by establishing national and state awareness, love of the homeland, trust in Pancasila, willingness to sacrifice for the nation and state and the initial ability. That was done to defend the country based on the decision of the Ministry of Education in Central Java Province, regarding Technical Guidelines Integration of Nationalism Materials [32]. The Scout Movement at PMD Gontor, including at PMD Gontor Putri 1 was designed with the Boy Scout curriculum established by Kwarnas, also supplemented by the PMD Gontor curriculum and particularly Pancajiwa PMD Gontor [33].

National and state awareness in scouting activities was carried out by compelling children to speak the Indonesian language that was good and right. The participants had to take part in a poem writing competition with the theme of heroism, group assignments to make flagpoles, and enforce red and white flags. Cultivating the attitude of loving the motherland was done by singing the Indonesian national anthem before giving scout material, respecting the flag during the ceremony, introducing natural wealth in the form of spices, as well as traditional games [34].

In fostering confidence in Pancasila, children were required to memorize Pancasila. Willingness to sacrifice for the nation and state done by helping a friend who was being stricken by disaster, such as being injured during training and then another friend helping to treat. While the initial ability to defend the country done through the selection of ceremonial officers to instill a brave attitude, memorize the Dasa dharma in the opening ceremony, and exercise to have a healthy body.

The values of diversity, a sense of multiculture, and ethnicity could be seen in everyday life at the cottage. When they were in class or the room, they

\footnotetext{
32 Dindiknas Jawa Tengah, Pedoman Teknis Pengintegrasian Materi Nasinalisme Sebagai Karakter Bangsa Melalui Ekstrakulikuler. (Semarang: Dindiknas Jawa Tengah, 2010), 5

${ }^{33}$ Interviewed with KH Ahmad Suharto, MA., Pengasuh PMD Gontor Putri 1 Mantingan, August 11, 2018 di kampus.

${ }^{34}$ Interviewed with Ustazah Ria Fauziah Salma, S.Pd., Mabikori di GP1 Mantingan Ngwai, August 12, 2018
}

blended in various tribes and regions. Even, there was a strict prohibition if in the room and class only in one tribe. The Gontor students reflected the existence of tribes and represent regional areas throughout Indonesia, even abroad. Although, they were from various regions and tribes, they merged into a culture of Islamic boarding school life, which was full souls of Pancajiwa [35].

National values developed through Scout extracurricular activities at PMD Gontor Ponorogo were:

\section{Religious}

Evidence of the religious values' achievement can be accomplished in the extracurricular activities of Scouting, both cognitive and psychomotor. Cognitively, the standby scouts (Siaga) and the Risers scouts (penggalang) of PMD Gontor Ponorogo can find out various kinds of religions in the world and especially in Indonesia with a variety of rituals and worship respectively [36]. Besides, the members of the Male Scouts must be able to apply what was good to do and bad things that must be left to the school environment, family, community, homeland and the nation according to the teachings of his religion.

The value of religiosity for members of the Male Scouts in PMD Gontor was emphasized in various aspects; increasing members' faith with various religious rituals such as congregational prayers both on campus and at campsites, reading the Qur'an, night devotions in various places that can enhance the spirituality of scout members. Besides that, a sense of tolerance fostered between organizations and between religions, with the motto "Above and for all groups" [37].

\section{Love to the Homeland}

Concrete evidence of achieving the value of patriotism can be achieved in scouting extracurricular activities, as evidenced by the appreciation of the students when attending the flag ceremony of being ready, living the song of Indonesia Raya and silence, respect for the brave and red flag. Through this appreciation, it can be seen in the daily learning that

35 Interviewed with KH Ahmad Suharto, MA., Pengasuh GP 1, August 11, 2018, at Campus GP 1 Mantingan Ngawi.

${ }^{36}$ Penjabaran SKU dikaitkan dengan Dhasa Darma Pramuka pertama "Taqwa kepada Tuhan yang Maha Esa" mencerminkan religiusitas yang harus dilaksanakan dengan seksama oleh semua anggota Pramuka. Lihat Ahmad Hasan Albana, Penjabaran SKU dan Aba Aba Isyarat (Ponorogo: Gerakan Pramuka, 2006).

${ }^{37}$ Interviewed with KH Ahmad Suharto, MA., Pengasuh PMD Gontor Putri 1 Mantingan, August 11, 2018 in campus. 
students of scouts appreciate their religious teachers and study hard in their aspirations to give the best to the unitary state of the Republic of Indonesia. Besides, some scout members participated in various state defense training through SAR (Search and Rescue) training, Saka Bahyangkara training.

\section{Disciplined}

All members of the standby scouts and raisers at PMD Gontor Ponorogo can have high discipline values which were reflected in a variety of ways. First, being on time from participating in scouting activities and learning at school. Everyday Santri always arrived earlier than the start of learning. Second, obeying regulations that scout students were always ready to obey the rules of school and boarding regulations. Third, discipline in all school and boarding activities and everyday life. The most effective disciplinary education in the Scouting Movement was the marching line, with marching training that will foster a stiff and agile attitude, a sense of unity, discipline, and others [38].

\section{Responsible}

Responsibility is in the ninth Dasa Darma. Scout members had a high sense of responsibility in school, boarding school, family, community, nation, and country. Reflected on students carrying out pickets that had been determined by each class teacher on schedule, dare to admit mistakes in school rules, and dare to correct these mistakes. In the cottage environment, carry out all the rules and all tasks assigned by the cottage. In the family environment, family rules can be implemented as stated in the two scouts on standby. In society, the nation and the State were responsible for learning earnestly to advance the State of Indonesia.

\section{Spirit of Nationality}

Scout members can be seen from their attitude towards understanding the unity of the Republic of Indonesia, the national anthem, the Indonesian flag, and its meaning, the symbol of the Indonesian State namely Pancasila and its meaning [ 39 ]. From this understanding, the scout students had a strong nationalism spirit.

In various scout exercises, competitions were often performed singing folk songs, scout songs, and national songs that reflected the spirit of nationalism.

\footnotetext{
${ }^{38}$ Koordinator Gugus Depan Pramuka PMD Gontor Putri, Pedoman Baris Berbaris (Ngawi: Koordinator Gugus Depan Gerakan Pramuka, no year), 1

${ }^{39}$ In a scouting ceremony, the implementation must be there: raising the Red and White, Reading the Pancasila, Reading the Scout Code of Honor, and Prayer. The decision of the Scout Kwarnas is in Number 178 of 1979, regarding the Instructions for organizing the ceremony in the Scout Movement.
}

Furthermore, in the scouting training, there was also a competition for the use of regional clothing where the scout members in Gontor came from tribes and regions in Indonesia, even abroad [40].

\section{Creativity}

Scout members can create national-themed outbound games and become outbound instructors to their younger siblings, with various games, magic games [41]. Creativity was also implemented in making pioneering which was a series of sticks knitted in such a way into various beautiful shapes and that can be seen in every scout training activity [42]. Here, the scout students' creativity was tested and it was well-equipped to become a good leader [43].

\section{Environmental Care}

Scout members can apply environmental care in schools and huts. The activities of become care scouts were done by doing cleaned each classroom according to the cleaning schedule, throwed trash in its place, cleaned around the school, and cottage environment. Those were applied every day which eventually became a culture of cleanliness in the school and the cottage. Besides, the attraction of the environment was also made by planting various flowers in the various parks that they made. Caring for the environment was a representation of a love for nature [44].

\section{Cooperation}

Scout members of cooperation between each other can be seen while in camp with one team, they were both setting up tents, looking for water, and cooking. In daily life at school and cottage can be seen when together in carrying out tasks, as when in the classroom reflected cooperation in cleaning classrooms according to the group, and when in the dormitory they were together [45].

\footnotetext{
${ }^{40}$ Interviewed with Muhammad Ali Ervan, wakil Koordinator, October 14, 2018, di PM Gontor Ponorogo

${ }^{41}$ Korp Pelatig Gerakan Pramuka PM Gontor, Aneka Permainan Pramuka (Ponorogo: Gugus Depan Gerakan Pramuka, 1990)

${ }^{42}$ Observation at PM Gontor, October 20, 2018 and at PM Gontor Female I, October 13, 2018

${ }^{43}$ To hone the creativity of scout members needed several manuals for scouting exercises such as knots and ties, pioneering, and various pioneering. See the Gontor PM Scout trainer Corps, Scouting Technical Guidelines (Ngawi: Gugus Depan Gerakan Pramuka Pondok Modern Gontor Ponorogo, no year)

${ }^{44}$ See laws of RI Nomor 12 of 2010 about Scout's movement.

${ }^{45}$ Observation on October 14, 2018
} 


\section{Bravery}

Dare is the Dasa Darma in point eighth. The courage of scout members appeared when the students (Santri) were assigned as ceremonial leaders in each activity. The coach did not need to appoint them and they were ready to appear. In daily learning, at the school scouts, students dared to ask questions with their class teachers firmly and politely.

\section{Pancajiwa [46]}

The national values that emerged in the research observations in the Gontor Ponorogo scouting extracurricular activities namely Pancajiwa were defined as the values that carried the behavior of the modern cottage Gontor Ponorogo. The essence of Islamic boarding school occupied in the contents or soul, not on the skin outside. In this content, a boarding school service was discovered for the people. Life in boarding schools was imbued with the ambiance that can be formulated in "Pancajiwa" as follows: (a) Soul of sincerity; (b) The soul of simplicity; (c) The spirit of being able to help oneself or self-help; (d) The spirit of democratic ukhuwah diniyah among students; (e) free soul [47].

Whereas the method used to be able to instill national values education through scouting extracurricular activities through exemplary, disciplinary enforcement, assignments, habituation, lectures, and educational games. Educational game was a very fun activity that was educational and beneficial to improve language skills, think, and get along with the environment. That case was done to strengthen and display the limbs, develop personality, close the relationship between caregivers and educators (students), then directed the activities of students, and so on.

\section{Encouraging factors for the implementation of nationality education in Boy Scout activities in Ponorogo PMD included:}

1. The inclusion of scouting education as a compulsory extra-curricular.

2. The quality of a qualified coach.

3. There was support from the leaders of Islamic boarding schools.

\footnotetext{
${ }^{46}$ K.H. Imam Zarkasyi, "Pembangunan Pondok Pondok Pesantren", in Al-Djami'ah, Nomor Chusus, Number 56, tahun ke IV, September-Nopember 1965, 26-27; K.H Imam Zarkasyi, Diktat Khutbah al-Iftita $>$ h: Pekan Perkenalan (Gontor: KMI, no year), p. 11-14; Nur Hadi Ihsan et. al., Profil Pondok Modern Darussalam gontor (Ponorogo: Darussalam Press, 2004), 15-16; Staf Sekretariat, Serba-serbi serba singkat tentang Pondok Modern Darussalam Gontor (Gontor: Perc. Darussalam, 1997), 1-8

${ }^{47}$ K.H. Imam Zarkasyi, "Pembangunan Pondok", in AlDjami'ah, 26-27.
}

Scouting forms in PMD Gontor Ponorogo and Gontor Putri Mantingan Ngawi included some names such as KMD, KML, KPD, KPL, as well as in Scouting exercises every Thursday, Perkajum, LP3, Saka Bhayangkara, SAR (Search and Rescue) and others, all of which were useful for inculcating and planting. building the nationalism attitude of the Santri nationality. The findings of the study were under Wahdjosumidjo's opinion in Poerwadarminto which revealed that extracurricular activities were held outside of school hours listed in the program arrangement under the circumstances and needs of the school [48].

The strategy used in the efforts of the cottage to develop scouting activities to realize the main scouting goal of building an attitude of nationalism was to provide innovation activities so that scouting activities were exciting. The students' habit of always respecting their homeland and nation as well as respecting the services of heroes was demonstrated by the implementation of the apple before and after the Boy Scout extracurricular activities. Furthermore, by providing material related to the insights of statehood, nationality, and diversity was an approach to instilling in students a sense of nationalism. That was consistent with the theory put forward by Noor Syam in Munandar which was an attitude of how education thinkers and implementers determine the policies, strategies, and basic patterns of our national education now for its effective role in the future [49].

Scouting activities had a great impact on students, by participating in scouting activities students can develop an attitude of nationalism that was an attitude of willingness to lead and be ready to be led, courage, responsibility, and a love of the homeland that students can explore through scouting activities. Scouts prepared many things related to the establishment of morals and character [50]. Moreover, scouts prepared the students on how to build a good attitude, which was always obedient to God Almighty, loving nature and fellow human beings; love for the motherland and the nation; discipline, courage, and loyalty; please help, be responsible and be trusted; clear in thinking, saying and doing; frugal, meticulous, and understated, diligent and skilled. That can be seen in the students who took a part in scouting activities always more prominent than other students who did not take a part. Scouts always trained courage, not only relying on brain intelligence however

\footnotetext{
${ }^{48}$ Poerwadarminto. Pembinaan ekstrakurikuler dan Penerapannya (Surabaya: Gamma, 2004), 201

${ }^{49}$ Utami Munandar, Strategi Mewujudkan Potensi Kreatif dan Bakat (Jakarta: Gramedia Pustaka Utama, 2009), 107

${ }^{50}$ In scouts there is a code of honor, and consists of; first, Satya Scout is a promise of scouts; secondly, Dharma Scout is a moral discipline of Scouts. Rizky, et al, Radiance Scout Introduction, 12-13
} 
also emotional intelligence which influences students' attitudes.

That was under the theory put forward by Djoyomartono in Ruslan that the attitude of nationalism defined one's efforts to develop children the importance of having ideas and behavior that were beneath the spirit of Indonesian nationalism and the spirit of Pancasila [51].

Scout extracurricular activities participants were students of PMD Gontor, and this activity was mandatory. So all students were ordered to participate in scouts [52 ]. Scouting activities were voluntary activities with many benefits that can be obtained, such as pouring creative power, forming a simple, independent soul, being responsible for him, and fostering a leadership spirit such as the ten principles that were contained in the Dasa dharma. There was no compulsion to participate in this activity because it was realized that each individual had their interests in different things.

That was under the statement expressed by Munandar [53], that every person had creative potential and the ability to express himself creatively, each in different fields and different levels. Scout members were expected to be a guide and an example for the younger generation because they were equipped with the discipline, independence, a responsibility that led to moral and character development. In line with the statement, Abbas [ 54 ] states that the scouting movement is a non-governmental body that seek to help the government and the community in developing society and nation, particularly as what happened in education through scouting activities using the Scouting Basic Principles and Scouting Methods [55]. One's

51 Ruslan Abdulgani, Roslan., Nasionalisme Asia. (Jakarta: Sinda, 2000), 183

52 Obligation to follow scout training at PMD Gontor actually since the establishment of the cottage in 1926 with Pandu Bintang Islam, even since 1937 the Islamic Star guide movement must be followed by all students of PMD Gontor. Ahmad Hasan Al-Bana, Penjabaran SKU dan Aba-Aba Isyarat (Ponorogo: Gerakan Pramuka PMD Gontor, 2006), 124

${ }^{53}$ Munandar, Pendidikan Memasuki Era Globalisasi (Jakarta: Erlangga, 2002), 67

${ }^{54}$ M. Amin Abbas, Pedoman Lengkap Gerakan Pramuka (Surabaya: Halim Jaya, 2005), 97

${ }^{55}$ The Basic Scouting Principle is a fundamental principle, which is the basis for thinking and acting; Faith and devotion in God Almighty; Caring for the nation, the State, fellow humans, and nature including its contents; Self-care; obey the scout honor code. While the keep-surface method is a way of progressive learning through; practice scout honor code; learning while doing, group systems, activities that are challenging and increasing and contain education under efforts to develop children would be the importance of having ideas and behaviors that were under the spirit of Indonesian nationalism and the spirit of Pancasila. The purpose of the program was to build virtuous students, instill a sense of love for the motherland, had a family attitude, and always applied the values of Pancasila, Dharma, and Trisatya principles as the foundation and principles of scouting.

Scout extracurricular programs designed by PMD Gontor Ponorogo can be supposed to be a quite good agenda. Seeing that not only activities in the school environment were preferred, meanwhile with programs outside the school, it was hoped that the objectives of all programs can be achieved. Similar to the theory expressed by Soegito [56], he reveals that the indicators of nationalism are, self-sacrifice, prioritizing unity, love for the motherland, and a reformer spirit and do not know giving up. That was also supported by Hertz's theory which states that the general characteristic of nationalism is the process of becoming the only nation. To become one, the nation is demanded by absolute necessity for the preservation of the nation, namely the similarity between members or citizens. That is only possible if there is equality between the members.

Scouting meant one of the extracurricular activities that could shape the self and personality of students who became Indonesian people who had high knowledge and could apply the noble values of the nation. With high discipline and solidarity in scouting, students from PMD Gontor Ponorogo would become the next generation of the nation with high potential. Khon in Abbas clarify that nationalism is an understanding which believed that the highest loyalties of individuals must be left to the nation.57 A very deep feeling of a close bond with the bloodbath with local traditions and official rulers in the region has always existed throughout history with different strengths. Even though regional traditions may not be displayed at PMD Gontor, certain events such as the introductory week at Gontor, or the competencies held by the boarding school could display the arts, culture, or traditions of local students, among others, were Aceh, Minangkabau, Java, Betawi, and others [58].

\footnotetext{
the spiritual and physical development of students; outdoor activities, skills sign system, separate unit systems for boys and girls; system among. Rizky, Radiance scout Interduction, 11-12.

56 A. T. Soegito, Pendidikan Pancasila.(Surabaya: UNNES Press, 2006), 95

${ }^{57}$ M. Amin Abbas, Pedoman Lengkap Gerakan Pramuka.(Surabaya: Halim Jaya, 2005), 79

${ }^{58}$ Interviewed with Ust Ahmad Suharto, M.A, pengasuh GP 1 on August 4, 2018 at PMD Female Gontor 1 Mantingan Ngawi.
} 
Various efforts were carried out by allocating funds according to need. Scoutmaster must have knowledge and experience in the field of scouting so that students can learn well. As a scoutmaster, at least had good human resources in the field of scout, because the coach was a place of learning and media for students. The more knowledge and experience the scoutmaster had, the more knowledge could be transformed into students. Consequently, scoutmaster education through the Basic Advanced Course (BAC) as well as the development period, and the holding of the Advanced Course (AAC) are promoted by PMD Gontor, and specifically, BAC was compulsory for fifth-grade students of KMI [59].

Provision of facilities in the form of facilities and infrastructure to support the extracurricular activities in scouts, the budget for extracurricular activities, especially scouts had entered the details of the cottage work budget [60]. PMD Gontor's attention to the running of scouting education and training was real. The most important thing to look at was the cottage's concern for the progress of the scout movement to date. Through scouting, education provided could make a positive contribution to the formation of the nationalism of the students of the cottage. As the purpose of the Scout Movement to form every member of the scout to have a personality that is faithful, pious, noble, patriotic, obedient, disciplined, upholds the nation's noble values, and has the life skills as a cadre of the nation in maintaining including built the Republic of the Republic Indonesia, practice Pancasila, and preserves the environment [61].

Collaboration with supporting parties in the activities of scouting care for the environment with the private sector and the government was carried out so that the activities can run smoothly. With this environmentally friendly scout program, it had many benefits, not only to students however to the environment and society. That case could trigger the community to participate in a cleanliness movement in

\footnotetext{
${ }^{59}$ It turns out that since 1950 during the Pandu Bintang Islam era, PMD Gontor has been carrying out scouting guide activities and was directly trained by the Chairperson of the Great Indonesian Islamic Guides Committee Mr. Ibrahim Mohammad ADCC from Jakarta. Moreover, in 1963, during the Scouting, Gontor always sent several Scout Guides to take part in the Cadika s.d Pusdika course. Ahmad Hasan Al-Bana, Penjabaran SKU dan Aba-Aba Isyarat, 124-125.

60 The scout financial budget was obtained through Santri contributions which were approved by the leadership of PMD Gontor and were conducted every semester. Obtaining finance with membership fees is legal by RI Law, Number 12, 2010, article 43, paragraph 1 .

${ }^{61}$ Laws of RI, Number 12 of 2010, concerning with Scout movement, article 4.
}

their environment, this activity also fostered students' caring attitude towards nature. It was under Sunardi's statement, that the attitude indicator of the second dharma is the love of nature and compassion among humans, the attitude that reflects the second dharma that is maintaining the cleanliness of the studio, class and school environment, helping to preserve nature, both flora and fauna, helping the poor, orphans, elderly parents, and visiting sick people [62].

Scouting activities at PMD Gontor were not only scouting on campus however also camping, which was called as Thursday-Friday Campsite, in educational institutions outside Islamic boarding school better known as Saturday-Sunday campsite. It was carried out alternately within the front groups in the Gontor PMD. Camping or admirers had benefits for scout members, Rizky remarks some of the benefits of camping include: strengthening the faith and piety to God Almighty; develop an attitude of democracy, cooperation, cooperation, and loyal friends; develop leadership skills; develop various kinds of skills; foster a love of nature in the care and preservation of the environment; enhance the subtlety of personal taste and discipline; developing and improving health knowledge, nutrition, and food preservation; develop and strengthen selfconfidence; develop the love of the motherland, and foster national unity; developing the ability to associate with other people and people (public and human relations); is a means of recreation that is healthy and fun and inexpensive; the arena of worship gives rise to and develops an entrepreneurial spirit, and expanding knowledge about nature directly [63].

No doubt, that scouting will educate its members on self-discipline. The term discipline in the context of Gontor's PMD was a very strategic educational instrument. As stated by $\mathrm{KH}$ Abdullah Syukri [64], that the strategy of coaching students in life on campus can be done with various kinds and strategies as follows:

1. Exemplary; highlighting the exemplary attitudes of the Kiai, teachers, caregivers, and Santri.

2. Creation of the environment; everything that was seen, heard, felt, done, and experienced daily must contain an element of education.

3. Direction; All activities began with a briefing, especially about the educational values contained therein.

4. Habituation; ran educational programs from the less severe with high discipline, sometimes coercion was also needed.

62 Bob Andri Sunardi, Boyman Ragam Latihan Pramuka (Bandung: Nuansa Muda, 2006), 9

${ }^{63}$ Rizky dkk, Radiance Scout Introduction, 90

${ }^{64} \mathrm{KH}$ Abdullah Syukri Zarkasyi, MA., Manajemen Pesantren; Pengalaman Pondok Modern Gontor (Ponorogo: Trimurti Press, 2005), 115 


\section{Assignment; involvement in organizing educational activities.}

\section{Constraints encountered to build nationalism through scout extracurricular activities at PMD Gontor Ponorogo}

The implementation of scout extracurricular activities encountered constraints regarding facilities and infrastructure including lack of funding sources. Pondok as an educational institution was reasonable to support and considered for the various activities that exist, therefore the fulfillment of needs related to activities to explore the potential of students was given to the maximum. The role of parents and the community was lacking, due to busyness or lack of understanding of the activity. The role of parents was very necessary for every activity carried out by children, parents can direct and motivate children to participate in extracurricular activities held at school. However, the lack of parental attention was an obstacle in-school efforts to develop students' potential through this scout.

The PMD Gontor community was a community with a minimum average education level of high school and part of the population earns the livelihood of farmers and fishermen. Consequently, their scout activities were still laid, so they did not fully understand that even and they lack understanding of how scouts including what were the benefits of these activities. It was consistent with the statement expressed by Munandar [65] that creative talent can develop in a supportive environment, but it can also be inhibited in an environment that does not support the development of that talent. In the family, at school, in the work environment and society, there must be appreciation and support for the attitudes and creative behavior of individuals and groups of individuals. Student activity was a top priority as a supporter of activities. Students were the main subject, so it should be obstacles related to the interests and motivations of them who needed to be given treatment because without the executing subject the extracurricular activities cannot run.

\section{Efforts made in overcoming obstacles in building students' nationalism through extracurricular activities at PMD Gontor Ponorogo}

The solution that can overcome the obstacles was that there must be a strong collaboration with various parties that support the sustainability of the Male Scout extracurricular activities. Sources of funds or finance must be granted by the cottage to support these activities. The scout movement was an educational movement, which always requires a fee. Without sufficient funds, it would be difficult to succeed in an educational work program. Although

\footnotetext{
${ }^{65}$ Munandar Utami, Strategi Mewujudkan Potensi Kreatif dan Bakat (Jakarta: Gramedia Pustaka Utama, 2009), 68
}

scouting education was trained to be economical and unpretentious, all the instruments and equipment in scouting activities always need money. Consequently, the group must try to prepare the funds needed to support the activities of scouts. As what has been stated by Rizky et al., [66] that preparatory work is very important because the success and failure of scout education in the future depend on the completeness of moral and material preparation, so it needs to be maximally sought.

The problem of interest was a fundamental problem that occurs in students, to overcome these obstacles was done by providing input to students related to the variety of activities and benefits of scouting. The role of parents, teachers, and the community was also very significant in overcoming the obstacle so that students wanted to take part in scouting and be able to take advantage of it. Parents were expected to be able to encourage their children, which could be done intensively at home. Teachers could also build students' motivation by approaching schools. Furthermore, teachers were parents of students in schools, so the teacher must educate students to progress the potential and abilities of their students.

The conflicting extracurricular activities schedule was expected to be able to be followed up by the school so that students could carry out extracurricular activities optimally. Students not only attend one kind of extracurricular activity at school, so the school must immediately arrange the schedule of all extracurricular activities held at school. That statement was under Munandar's [67] statement, he reveals that the purpose of education is to provide an environment which allows students to develop their abilities optimally, then they can manifest themselves and function fully, beneath their personal and community needs.

\section{CONCLUSION}

Based on the results of research and discussion that has been described regarding the efforts to develop a nationalist aspect on students through scout extracurricular activities at PMD Gontor Ponorogo, in this section, the conclusions of the study are summarized as follows;

1. Scouting education and training in PMD Gontor are mandatory for all students; Santri class one to five as members of Front line, Santri of class five as advisors and assistants to assist the group; the teachers act as the master group advisors. Scouting education is mandatory for class five in BAC (Basic Advanced Course) activities, and compulsory for class six in AAC activities

\footnotetext{
${ }^{66}$ Rizky, et al., Radiance Scout Introduction, 42

${ }^{67}$ Munandar, Utami., Strategi Mewujudkan Potensi Kreatif dan Bakat (Jakarta: Gramedia Pustaka Utama, 2009), 4
} 
(Advanced Advanced Course), while BTC (Basic Training Course) and ATC (Advanced Training Course) are followed by some teachers who are interested in activities scout. Regular boarding training is held every Thursday from $2.30 \mathrm{pm}$ until $4 \mathrm{pm}$.

2. The strategy of developing national insight is carried out through instance, the creation of an educational environment, direction, habituation, assignment. Through those strategies, national values will be shown as national and state awareness, national spirit, love of the motherland, diversity, respecting the red and white flag, trusting the foundation of the Pancasila state, ready to lead and ready to be led, religious, disciplined, responsible, creativity, caring for the environment, cooperation, courage, foreign country, and values of Pancajiwa such as sincerity, simplicity, independence, Ukhuwah Islamiyah, and freedom.

3. Factors that encourage the implementation of nationality education toward Scouting activities in Gontor Ponorogo PMD include infrastructure, the inclusion of scouting education as an extracurricular mandatory, the quality of qualified coaches, and the support of leaders of Islamic boarding school.

4. The obstacles that are faced to build nationalism through scout extracurricular activities in PMD Gontor Ponorogo, including the presence of several parents and the surrounding community who are less supportive in developing the potential of students through this scout.

5. There is effective collaboration with various parties that support and the source of funds issued by the cottage to support these activities in the continuation of scout extracurricular activities. 